WIENER SLAVISTISCHES JAHRBUCH, Band 53/2007, 241-246

(C) 2007 by Österreichische Akademie der Wissenschaften, Wien

ELIZABETA JENKO

\title{
Jezikovna praksa pri pouku slovenščine kot tuji jezik
}

\begin{abstract}
Im Rahmen der politischen und wirtschaftlichen Veränderungen in den vergangenen zwei Jahrzehnten ist das Interesse an der slowenischen Sprache als neuer Staatssprache der EU merkbar gestiegen, sei es aus beruflichen, privaten oder auch aus wissenschaftlichen Gründen. Da sich die Schulsysteme in Europa den neuen sprachpolitischen Gegebenheiten nur sehr schleppend anpassen, erfolgt der Unterricht des Slowenischen als Fremdsprache zumeist in der Erwachsenenbildung. Ein Vergleich der Programme an einigen Institutionen zeigt diesbezüglich bedeutende quantitative und qualitative Unterschiede. Während im außeruniversitären Bereich der kommunikative Zugang mit rein pragmatischen Zielen Vorrang hat, stehen die Sprachkurse im Rahmen eines philologischen Studiums an der Universität vor der Aufgabe, parallel zur sprachpraktischen Ausbildung auch den kognitiven Ansprüchen der Studierenden gerecht zu werden und die sprachwissenschaftliche sowie literatur- und kulturwissenschaftliche Ausbildung entsprechend zu unterstützen. Dabei wird mit authentischen Texten und Methoden des erfahrungsorientierten Fremdsprachenunterrichts gearbeitet, denn der effektivste Spracherwerb findet vor allem durch regelmäßigen Kontakt mit der Sprachpraxis in Form von Originaltexten statt.
\end{abstract}

Politične, gospodarske in družbene spremembe v Evropi in po svetu zahtevajo povečano znanje tujih jezikov in $\mathrm{s}$ tem tudi nov pristop pri pouku tujih jezikov, ne nazadnje prav slovenščine, ki postaja kot državni jezik nove članice Evropske unije iz najrazličnejših razlogov zanimiva za vedno širši krog ljudi. Povpraševanje po tečajih slovenščine narašča, na eni strani zaradi službenih obveznosti, na drugi strani iz zasebnih razlogov, prav tako pa je interes usmerjen na področje znanstvenoraziskovalnega dela. Temelj vsakršne dejavnosti na kateremkoli omenjenem področju pa je dobro znanje in poznavanje jezika.

Evropski šolski sistemi se novim okoliščinam še niso prilagodili, zato poteka pouk slovanskih jezikov večinoma v izobraževalnih ustanovah za odrasle. Na Dunaju so to bodisi zasebni tečaji bodisi javne ustanove kot denimo Ljudske visoke šole (Volkshochschule) ali pa npr. tudi avstrijska Akademija za obramboslovje. Precejšnje število interesentov in interesentk za slovenski jezik pa se zbere prav na Univerzi.

Če primerjamo programe, po katerih se slovenski jezik poučuje na raznih ustanovah, se ti glede na naravo tečaja močno razlikujejo. Medtem ko se tečaji na Ljudskih 
visokih šolah prilagajajo zlasti potrebam najpreprostejšega vsakdanjega sporazumevanja, v okviru katerega se na posameznih stopnjah, ki obsegajo po okoli trideset učnih enot, obravnavajo teme tipa „V trgovini“, „V restavraciji“, „Koliko je ura?“ ipd., se Akademija za obramboslovje ravna po NATO-vem Opisu ravni jezikovnega znanja, ki je po besedah odgovornega polkovnika dr. Ernsta podoben Skupnemu evropskemu jezikovnemu okviru. Razlikuje štiri stopnje, za katere sta predvidena po dva tečaja. Vsak tečaj obsega 150 učnih enot. To pomeni, da je za dosego cilja dobrega uporabnika namenjenih najmanj 1200 učnih enot, za jezike, ki se jih nemško govoreči težje naučijo, kamor spadajo tudi slovanski jeziki, pa tudi do dvakrat toliko.

Po programu Centra za slovenščino kot drugi/tuji jezik v Ljubljani je v Celoletni šoli slovenskega jezika predvidenih približno 560 učnih enot, da se učenci in učenke $\mathrm{z}$ začetniške stopnje povzpnejo na izpopolnjevalno raven, ki jim omogoča

opravljanje izpita iz znanja slovenščine (npr. za vpis na slovenski univerzi, za pridobitev delovnega dovoljenja idr.). Vsi, ki že imajo določeno predznanje ali pa njihov prvi jezik sodi v skupino slovanskih jezikov, lahko to stopnjo dosežejo v krajšem času (npr. v enem delu Celoletne šole), v vsakem primeru pa bistveno napredujejo v znanju slovenskega jezika. (http://www.centerslo.net, 23.8.2006)

Pri tem udeleženci in udeleženke tečajev vsaj osem mesecev živijo v slovensko govorečem okolju, kjer jim je jezikovna praksa na voljo 24 ur na dan.

V okviru celotnega študija slovenščine oz. kateregakoli slovanskega jezika na Univerzi pa je praktični jezikovni izobrazbi v obliki jezikovnih tečajev in praktikumov odmerjenih manj kot 350 učnih enot. Prvo leto poteka jezikovni pouk intenzivneje, nato pa stopi v ozadje in prevzame spremljevalno vlogo znanstvenega izobraževanja.

Primerjava teh podatkov nam jasno kaže, da velja s časom, ki nam je na voljo za jezikovno izobrazbo, katero je potrebno uskladiti z zahtevami študijskega načrta oz. literarnostrokovno, jezikoslovno in kulturnoznanstveno vsebino le-tega, kar najbolj smotrno in gospodarno ravnati. Postavlja se torej vprašanje, kako zmanjšati razpon med potrebo in ponudbo. Kako izbrati čim bolj učinkovite pristope do formalne plati neznanega jezika kot solidnega temelja za znanstvenoraziskovalno delo na tem področju, ne da bi ob tem zanemarili usvajanja sporazumevalnih zmožnosti ter novih kulturnih in družbenih vsebin, ki jih posredujemo vzporedno z jezikom kot pogoj za delo v praksi?

Pri načrtovanju vsebin in vaj izhajamo iz dejstva, da igra pri jezikovnem pouku v okviru filološkega študija pomembno vlogo kognitivna komponenta, kar upoštevamo pri izbiri in pripravi besedilnega gradiva za pouk. Učenje jezika je povezano z uvajanjem v znanstveno delo. Študentke in študentje v okviru svojega študija obiskujejo jezikovne vaje, hkrati pa spoznavajo tudi jezikoslovno in literarno teorijo ter poslušajo predavanja o slovenski književnosti in kulturi ter o slovenskem jezikoslovju. Besedila, ki jih obravnavamo med jezikovnim poukom, je treba izbirati tako, da upoštevajo intelektualne zmožnosti študirajočih in so jim obenem tudi praktični zgled in opora pri znanstvenem obravnavanju jezika ter pri analiziranju jezikovnih 
prvin. Prav tako pa morajo biti usmerjena v pragmatičnost in samostojno ustvarjalnost ter ponujati vpogled $\mathrm{v}$ kulturno, zgodovinsko, politično in socialno dogajanje ciljnega jezika.

Sodobna didaktika pouka tujih jezikov se opira na naslovne skupine in njihove potrebe ter temelji na jezikovni rabi. Le-ta na individualni ravni ni predvidljiva in se glede na okoliščine lahko močno razlikuje. Pisanje poslovnih pisem denimo terja povsem drugačne jezikovne veščine kot branje leposlovja ali poslušanje radijskih in televizijskih poročil.

V Skupnem evropskem jezikovnem okviru oz. na stopnji B1 tega okvira, znani tudi kot Sporazumevalni prag za slovenščino, ki opredeluje sporazumevalne zmožnosti neodvisnega uporabnika, je jezikovna praksa opisana kot

sposobnost rabe jezika $\mathrm{v}$ konkretni situaciji. Zato so v 5. poglavju Jezikovne funkcije podani osnovni nameni, ki se lahko uresničujejo z jezikovnimi sredstvi. To so npr. opisovanje, poizvedovanje, odklanjanje, zahvaljevanje, opravičevanje, izražanje čustev idr. (Ferbežar 2004: 10),

ali:

B1 - ALTE 2 (sporazumevalni prag - neodvisni uporabnik): Sposobnost omejenega izražanja $\mathrm{v}$ znanih situacijah, tudi sposobnost reagiranja $\mathrm{v}$ nepredvidljivih situacijah. (PirihSvetina 2004: 9)

Pojem jezikovne prakse je jasno osredotočen na komunikativni pristop oziroma na pojem vsakdanje jezikovne prakse. Omenjena pa je tudi pomembnost seznanjanja s sociokulturnim kontekstom ali vsaj zavedanja možnega pomena slednjega za uspešno sporazumevanje (Ferbežar 2004: 11). Vendar pa je poglavje o sociokulturnih zmožnostih obravnavano zelo splošno in obrobno. Tam lahko najdemo na nekaj straneh strnjene informacije o družbenih konvencijah kot sta to vikanje in tikanje, o pravilih glede telesne govorice (prikimovanje oz. odkimovanje ipd.), o okvirnih družbenih navadah (običajni časi dnevnih obrokov, delovni čas ipd.) in o osnovnih zgodovinskih in geografskih podatkih o Sloveniji (Ferbežar 2004: 162-167).

Primerjava ciljev Evropskih ravni jezikovnega znanja s študijskim načrtom slovenističnega študija na Dunaju (in drugod po Evropi izven matične države) pa kaže, da je treba $\mathrm{v}$ tem kontekstu pojmovanje jezikovne prakse razširiti. Študijski načrt denimo predvideva dobro poznavanje starejše oz. kanonizirane in sodobne slovenske književnosti in branje izvirnih literarnih del, seznanjenost z literarno teorijo in zgodovino ter s civilizacijskimi ozadji slovenskega jezika in še kaj. Prav tako se morajo študentje in študentke razmeroma zgodaj seznaniti z jezikoslovnimi publikacijami $v$ slovenskem jeziku, za kar je potrebno poznavanje slovnice $\mathrm{v}$ teoriji in obvladanje slovničnih pravil, slovenske jezikoslovne terminologije in literarnega metajezika. Če želimo študirajočim ob učenju tujega jezika, ki obsega tako teorijo kot prakso jezika in ki se začne na začetniški oz. ničti stopnji, omogočiti kakovosten filološki študij, je z didaktičnega vidika 21. stoletja celostno obravnavanje jezika nepogrešljivo. Študentom in študentkam moramo vzporedno posredovati tako pragmatično plat jezika, torej komunikacijske zmožnosti, kot tudi formalno in kognitivno plat jezika, torej 
znanje o jeziku in sociokulturnem kontekstu le-tega. Ne nazadnje je treba študirajoče usposobiti za medkulturno komunikacijo, ki zajema sposobnost za razumevanje specifičnih kulturnih pojavov in primerno rabo jezika v skladu s pravili družbe ciljnega jezika.

Raziskava, ki je pomembnost jezikovnih zmožnosti slušnega in bralnega razumevanja, govorjenja in pisanja ocenila $v$ razmerju 8:7:4:2 (Rampillon 1996: 65) nas opozarja, da velja zlasti v začetni fazi učenja posvetiti več pozornosti bralnemu (in slušnemu) razumevanju jezika, in to v njegovi izvirni podobi, kar predstavlja pomemben del jezikovne prakse študirajočih. Za spoznavanje slovenske književnosti, ki poteka vzporedno z učenjem jezika, je obvladovanje tega dela jezikovne prakse ključnega pomena.

Sposobnost literarnega branja je zato sposobnost zavestnega doživljanja, razumevanja in vrednotenja vsebine in oblike raznovrstnih literarnih besedil. (Krakar-Vogel 2004: 41)

Prav tako pomeni ukvarjanje tako $\mathrm{z}$ umetnostnimi kot tudi z neumetnostnimi besedili neposreden stik s slovensko kulturno in družbeno resničnostjo in potemtakem spoznavanje jezikovne prakse.

$\mathrm{V}$ zvezi s tem si je vredno ogledati produktivnost slovenske didaktične dejavnosti 20./21. stoletja, ki je porodila precejšnje število sodobnih učnih pripomočkov. Ti omogočajo prožen in živahen pouk slovenskega jezika na podlagi komunikacijskega pristopa. Vendar pa se tudi novejši učbeniki zlasti za začetniško stopnjo z nekaj izjemami skoraj dosledno izogibajo tako izvirnim kot tudi literarnim besedilom, slednjim bržkone zato, ker ne posredujejo vsakdanjih sporazumevalnih vzorcev. Učne enote navadno vsebujejo stvarnosti prilagojene in prirejene dialoge, ustrezno besedišče in razlage izbranih slovničnih poglavij po vnaprej določenem vrstnem redu. Šele Jezikovod (Ferbežar - Domadenik 2005), učbenik za izpopolnjevalno stopnjo, seznanja študirajoče z izvirnimi besedili in vsebinami, torej z jezikovno resničnostjo. Vendar nizka stopnja jezikovnega znanja ne sme biti ovira za ukvarjanje z izvirnimi besedili, stopnji znanja je treba prilagodite le vaje, ki morajo tudi iz motivacijskih razlogov ustrezati interesom študirajočih. Vaje je treba prirediti tako, da pomagajo študentom in študentkam razvijati tehnike in strategije, ki omogočajo učinkovit in čim bolj neposreden dostop do besedila in s tem do jezika in njegovega kulturnega ozadja. Strateški pristopi, ki lajšajo delo s tujejezičnimi besedili so lahko kontekstualno povezovanje imen in mednarodnih izrazov, dojemanje ključnih besed in prepoznavanje le-teh $\mathrm{v}$ spremenjenih skladenjskih okoliščinah, smiselno razčlenjevanje besedila in celostno dojemanje pomenskih enot, formalno interpretiranje besednih zvez in skladenjskih vzorcev na podlagi podobnosti struktur in še marsikaj drugega, odvisno zlasti od predznanja učečih se. Izkušnje namreč kažejo, da prav izvirna besedila pritegnejo in spodbujajo k samostojnemu ukvarjanju $\mathrm{z}$ jezikom, tako da se znanje postopoma ustvarja s transformacijo izkušenj. Študentje in študentke si tako pod znanstvenim mentorstvom pridobivajo orodje za samostojno učenje, kamor spada denimo uporaba slovarjev in drugih priročnikov, saj terja suvereno delo z njimi precejšnjo mero izkušenosti. 
$\mathrm{V}$ okviru bilateralnega slovensko-avstrijskega projekta $\mathrm{v}$ zvezi s proizvodnjo učnih pripomočkov za pouk po opisanih načelih je kot prvi modul avtentičnih besedil za učenje slovenščine nastala Zvočna čitanka za pouk slovenščine v dveh delih. Gre za zbirko avtentičnih besedil iz vsakdanjega življenja, preko katerih se študentje in študentke seznanjajo z zvrstnostjo slovenskega jezika od narečja do zborne slovenščine in se urijo v slušnem razumevanju jezika, kot se pojavlja v praksi (Jenko et al. 2002), in pa za zbirko odlomkov slovenskih literarnih besedil skozi čas v knjižni obliki (Pezdirc-Bartol 2003) oz. posnetih na zgoščenki (Krakar-Vogel - Pezdirc-Bartol 2002).

Zvočno gradivo predstavljajo torej odlomki umetnostnih besedil tako poezije in proze kot tudi dramatike iz različnih obdobij in pa primeri iz vsakdanjega življenja, ki so z malenkostnimi izjemami neprirejeni, posneti v naravnih okoliščinah z vsemi značilnostmi govorjenega jezika kot so to razni šumi, ki spremljajo govor, različni glasovi in govorni tempo, intonacija, skladenjske nepravilnosti pogovornega oz. govorjenega jezika itd. Delo z Zvočno čitanko učence in učenke slovenskega jezika v tujini privaja slušnemu razumevanju jezika, kot se pojavlja v praksi. Knjiga vsebuje transkripcije besedil ter navodila za delo $\mathrm{z}$ besedili oz. predloge za vaje. Po istih načelih je nastala zbirka avtentičnih neumetnostnih besedil za usvajanje sporazumevalne zmožnosti branja (Jenko 2006).

Širok razpon med potrebami jezikovne izobrazbe in ponudbo na tem področju zahteva nujno izobraževanje izven študijskega načrta. Vzporedno z vajami v okviru študijskih obveznosti zato potekajo na Inštitutu za slavistiko dunajske Univerze dejavnosti, ki omogočajo študirajočim stalen stik s Slovenijo, katere bližino izkoriščamo na različne načine. Študijski vsakdan skušamo popestriti z različnimi prireditvami. Med letoma 2001 in 2006 so se nam v okviru Slovenskih večerov s svojim delom predstavili mnogi predstavniki in predstavnice slovenskega kulturnega, znanstvenega in političnega življenja, kot npr. Silvija Borovnik, Miran Hladnik, Maja Novak, Zoran Predin, Adi Smolar, Jurij Souček, Ivo Vajgl in Mia Žnidarič, da jih omenim le nekaj. Sodelovanje pri projektih Centra za slovenščino kot drugi/tuji jezik dopolnjuje naš program. Zelo uspešni so bili denimo Svetovni dnevi slovenskega filma leta 2005, prav tako Svetovni dnevi slovenske literature v študijskem letu 2006/07. Pri študentih in študentkah so posebej priljubljeni jezikovni praktikumi, v okviru katerih spoznavajo slovenska mesta in pokrajine tako $\mathrm{v}$ teoriji (vaje) kot $\mathrm{v}$ praksi (ekskurzije). V istem obdobju smo tako spoznali Idrijo z okolico, Ptuj z okolico, Primorsko, Gorenjsko, Ljubljano in Belo krajino.

Poletni Seminar slovenskega jezika, literature in kulture ter Poletna šola slovenskega jezika v Ljubljani in v Kopru zaokrožajo slovenistično izobraževanje izven matične univerze. Evropski izobraževalni program Socrates spodbuja mobilnost študirajočih in povezovanje Univerz po Evropi ter omogoča mladim, da dalj časa bivajo v državi ciljnega jezika in tako $\mathrm{v}$ živo spoznavajo tako študijske programe kot vsakdanjo jezikovno prakso. 


\section{Literatura}

Bausch - Christ - Krumm ${ }^{2}$ 1995: K.-R. Bausch - H. Christ - H.-J. Krumm, Handbuch der Fremdsprachendidaktik, Tübingen und Basel

Crystall 1993:

Ferbežar 2004:

D. Crystall, Die Cambridge Enzyklopädie der Sprache, Frankfurt

Ferbežar - Domadenik 2005:I. Ferbežar - N. Domadenik, Jezikovod, Ljubljana

Jenko - Pečnik - Reichmayr 2002: E. Jenko - D. Pečnik - M. Reichmayr, Zvočna čitanka za pouk slovenščine, Klagenfurt/Celovec

Jenko 2006: $\quad$ E. Jenko, Z branjem do slovenščine, Klagenfurt/Celovec

Krakar-Vogel - Pezdirc-Bartol 2002: B. Krakar-Vogel - M. Pezdirc-Bartol, Zvočna čitanka, Ljubljana

Krakar-Vogel 2004: $\quad$ B. Krakar-Vogel, Poglavja iz didaktike književnosti, Ljubljana

Pezdirc-Bartol 2003: M. Pezdirc-Bartol, Literarna sestavljanka, Ljubljana

Pirih-Svetina 2004: N. Pirih-Svetina et. al., Opisi ravni jezikovnega znanja, Kraków

Pirih-Svetina - Ponikvar 2003: N. Pirih-Svetina - A. Ponikvar, A, B, C, 1, 2, 3, gremo,



Elizabeta Jenko

Institut für Slawistik der Universität Wien

Universitätscampus AAKH, Hof 3

Spitalgasse 2, A-1090 Wien

elizabeta.jenko@univie.ac.at 